\title{
ФИЗИОЛОГИЧЕСКИЙ СТАТУС И КАЧЕСТВО ШКУРОК У МОЛОДНЯКА СЕРЕБРИСТО-ЧЕРНОЙ ЛИСИЦЫ (Vulpes vulpes L.) ПРИ ПРИМЕНЕНИИ ПРОТИВОПАРАЗИТАРНОГО ПРЕПАРАТА НИАЦИД-ГРАНУЛЫ ПЛЮС С БИОАКТИВНЫМ КЕРАТИНОМ КАК КОРМОВОЙ ДОБАВКОЙ
}

\author{
А.И. САПОЖНИКОВА 1 , К.В. ЕСЕПЕНОК ${ }^{1}$, Г.Ю. КОСОВСКИЙ 2 , Е.А. ТИНАЕВА ${ }^{1}$, \\ М.Н. МИРЗАЕВ ${ }^{2}$, Е.Г. КВАРТНИКОВА ${ }^{2}$, Б.В. НОВИКОВ ${ }^{2}$, Т.М. ЧЕКАЛОВА 2
}

За последние годы среди плотоядных животных, в том числе серебристо-черных лисиц, участились случаи нематодозов, причиняющих существенный экономический ущерб. От глистных инвазий в наиболышей степени страдает молодняк. В современной ветеринарной мировой практике наиболее перспективными признают антгельминтики нового поколения, в частности средства на основе авермектинов. Ни в России, ни за рубежом до настоящего времени препараты кератина в сочетании с антгельминтиками при промышленном разведении пушных зверей не использовались. В представленной нами работе впервые экспериментально доказано, что применение антгельминтика нового поколения Ниащид-гранулы плюс в сочетании с серосодержащей кормовой добавкой Биоактивный кератин способствует повышению показателей качества волосяного покрова и улучшению товарных свойств шкурок серебристо-черной лисицы (сортность, размер, группа дефектности, густота меха). В производственных условиях (АО «Племенной зверосовхоз «Салтыковский», Московская обл., 2017-2018 годы) мы изучили физиологический эффект от сочетанного использования Биоактивного кератина и антгельминтика на основе авермектина при выращивании молодняка серебристо-черной лисицы с оценкой качества получаемой шкурковой продукции. Препарат Ниацид-гранулы плюс (ООО «НПО «Экобиовет», Россия; МГАВМиБМВА им. К.И. Скрябина, Россия) представляет собой гранулы коричневого цвета (масса на упаковку - 300-400 г) с содержанием абамектина $B_{1 a} 85 \%$ и абамектина $B_{1 b} 15 \%$; срок хранения не менее 21 мес. Биоактивный кератин (МГАВМиБ-МВА им. К.И. Скрябина) - монопродукт, полученный из очеса шерсти и содержащий $98 \%$ нативного белка, имеет вид однородной жидкой массы, цвет от светло серо-бежевого до темно серо-бежевого, со специфическим запахом, массовой долей сухого вещества 3-10 \%, массовой долей кератина 95-98 \% (допустимый срок хранения - не менее 2 лет). Препараты Ниацид-гранулы плюс и Биоактивный кератин относятся к IV классу токсичности. Показано, что сочетанное использование Ниацид-гранулы плюс и Биоактивного кератина достоверно усиливает эффект каждого препарата в отдельности. Установлено, что дегельминтизация молодняка серебристо-черной лисицы (Vulpes vulpes L.) в возрасте 2 мес препаратом Ниацид-гранулы плюс и последующее применение биоактивного кератина в качестве серосодержащей кормовой добавки к основному рациону достоверно влияют на прирост живой массы. При комплексном использовании препаратов Ниацид-гранулы плюс и Биоактивный кератин масса щенков была на 9,1\% выше, чем в контроле (соответственно $t_{\text {факт. }}=7,40 \geq t_{\text {табл }}=2,1$ при $\mathrm{p}=0,05$ и $t_{\text {факт. }}=0,81 \leq t_{\text {табл. }}=2,1$ при $\left.\mathrm{p}=0,05\right)$. Общеклинические показатели крови также улучшались. Следовательно, эти препараты способствуют ускоренной нормализации физиологического статуса молодняка серебристо-черной лисицы. При применении обоих препаратов масса молодняка увеличилась на $30,4 \%$, площадь полученных шкурок - на $18,4 \%$, густота волосяного покрова - на 24,6 \% по сравнению с аналогичными показателями для интактных зверей, что служит подтверждением эффективности совместного применения изученных препаратов. Ниацидгранулы плюс рекомендуется использовать 2-кратно с интервалом 10 сут в возрасте молодняка серебристо-черной лисицы 2 мес, кормовую добавку Биоактивный кератин - шестью циклами (5-суточные курсы с 10-суточными перерывами).

Ключевые слова: Vulpes vulpes L., серебристо-черная лисица, молодняк, ниацид-гранулы плюс, авермектин, биоактивный кератин, живая масса, показатели крови, качество шкурок.

У пушных зверей (1) формирование волосяного покрова и качество шкурок, обусловленное породными особенностями, зависят от физиологического состояния особей, которое, в свою очередь, определяется условиями кормления (2), содержания (3), профилактических и лечебных мероприятий (4). В последние годы среди плотоядных животных, в том числе серебристо-черных лисиц, участились случаи нематодозов. От глистных инвазий особенно сильно страдает молодняк. Как правило, глистные заболевания вызывают истощение, у зверей снижается воспроизводительная способность, у молодняка серебристо-черной лисицы и других плотоядных 
замедляется рост и развитие $(5,6)$. У пушных зверей могут паразитировать более 70 видов различных нематод (7). Наибольшее экономическое значение имеют токсокароз, токсаскаридоз, трихинеллез. Несмотря на то, что в настоящее время существует достаточно широкий ассортимент антигельминтных средств (например, Ивомек®, ЗАО «Нита-ФАРМ», Россия; Нилверм - Nilverm ${ }^{\circledR}$, «Pliva», Хорватия; Альбамелин ${ }^{\circledR}$, АО Завод «Ветеринарные препараты», Россия), до конца победить гельминтные инвазии не удается. Известно, что любой антгельминтик уничтожает только взрослых глистов, яйца же гельминтов остаются в организме даже после проведения дегельминтизации. Поэтому при установленном факте глистной инвазии необходимо проводить 2-кратную, с интервалом 10 сут, обработку зверей для того, чтобы из яиц к моменту второй обработки уже появились неполовозрелые особи, еще не способные отложить свое потомство (5).

Наиболее перспективными признаются антгельминтики нового поколения, в частности средства на основе авермектинов (8-10). Ниацидгранулы плюс (ООО «НПО «Экобиовет», МГАВМиБ-МВА им. К.И. Скрябина, Россия) - одна из последних разработок в линейке антгельминтиков авермектинового ряда (10), однако в звероводстве он пока не применялся. По механизму действия это препарат нейротоксинного типа (действующее вещество блокирует и тормозит передачу нервного импульса, вызывая паралич, а затем и гибель нематод) (8).

Ранее мы рассматривали различные области практического применения кератинсодержащих препаратов (11), в частности в косметологии и медицине (12-14). Препараты гидролизованного кератина могут использоваться и в животноводстве (15), а также в звероводстве как активные кормовые добавки, влияющие на состояние волосяного покрова шкурки (11). В составе гидролизованного кератина содержится аминокислота цистеин, которая относится к тиольным соединениям. Механизм биохимического действия тиолов заключается в способности восстанавливать дисульфидные связи при патологических нарушениях, инактивировать токсические агенты, а также повышать содержание сульфгидрильных групп, обеспечивая антиоксидантный эффект $(16,17)$. Тиольные соединения в первую очередь подвергаются воздействию активных кислородных радикалов, что предохраняет от их влияния функциональные группы биологических молекул и клеточных мембран $(18,19)$.

До настоящего времени препараты кератина в сочетании с антгельминтиками при промышленном разведении пушных зверей не применялись, хотя комплексное использование биологически активных веществ (20-22) и ветеринарных препаратов признается весьма результативным («Видаль Ветеринар 2019. Лекарственные средства для ветеринарного применения в России». М., 2018). Однако данные об эффективности этих веществ, их дозах (23), особенностях влияния на организм пушных зверей, в частности серебристо-черных лисиц, крайне ограничены и чрезвычайно разрознены (24). В единичных публикациях сообщалось о раздельном применении кератина на норках (Баранцева О.В. «Технология получения кератинсодержащей кормовой добавки и оценка ее влияния на качество шкурок норки». Канд. дис. М., 2011), кератина, коллагена и меланина на хорях (11).

В представленном исследовании впервые проведена комплексная оценка противопаразитарного препарата Ниацид-гранулы плюс на убойном молодняке серебристо-черной лисицы, обоснована возможность использовать продукт рециклинга кератинсодержащих отходов - препарат Биоактивный кератин в качестве серосодержащей кормовой добавки в основной рацион серебристо-черных лисиц и отработана ее оптимальная 
дозировка при добавлении в корм. Впервые экспериментально доказано, что антгельминтик Ниацид-гранулы плюс в сочетании с серосодержащей кормовой добавкой Биоактивный кератин способствует повышению показателей качества волосяного покрова и улучшению товарных свойств шкурок серебристо-черной лисицы (сортность, размер, группа дефектности, густота).

Цель работы - определить физиологический эффект от сочетанного использования биоактивного кератина и антгельминтика на основе авермектина при выращивании молодняка серебристо-черной лисицы и оценить качество получаемой шкурковой продукции.

Методика. В опыте использовали препарат Ниацид-гранулы плюс (ООО «НПО «Экобиовет») и биоактивный кератин (МГАВМиБ-МВА им. К.И. Скрябина) из очеса тонкой овечьей шерсти - возвратного отхода при переработке шерсти в текстильной промышленности (25).

Токсичность препарата Ниацид-гранулы плюс и кормовой добавки Биоактивный кератин оценивали по ГОСТ 12.1.007-76 «Вредные вещества. Классификация и общие требования безопасности», а также на основе требований, изложенных в ГОСТ 32296-2013 «Методы испытаний химической продукции на организм человека. Основные требования к проведению испытаний по оценке острой токсичности при внутрижелудочном поступлении методом фиксированной дозы». В качестве подопытных лабораторных животных использовали 70 беспородных белых мышей и 70 аутбредных крыс линии Wistar, объединенных в группы аналогов по живой массе. Эксперименты выполняли в соответствии с протоколами Женевской конвенции и принципами надлежащей лабораторной практики (Национальный стандарт Российской Федерации ГОСТ Р 53434-2009), а также согласно рекомендациям «The Guide for the Care and Use of Laboratory Animals (National Academy Press Washington, D.C. 1996)». Рассчитывали средние летальные дозы (26).

Для оценки эффективности раздельного и сочетанного применения антгельминтика и биоактивной кормовой добавки 2-месячных щенков серебристо-черной лисицы (Vulpes vulpes L.) методом аналогов с учетом дат рождения и живой массы разделили на 4 группы по 10 особей в каждой (АО «Племенной зверосовхоз «Салтыковский», 2017 год). Препараты давали животным в соответствии со следующей схемой: в I группе в принятый в хозяйстве основной рацион (OP) зверей дважды добавляли антгельминтик Ниацид-гранулы плюс (ДВ 200 мкг/гранула на 1 кг массы животного с интервалом 10 сут, начиная с 1-х сут опыта); во II группе в ОР добавляли антгельминтик Ниацид-гранулы плюс в той же дозе и препарат Биоактивный кератин в количестве $0,2 \%$ от суточной нормы белка (6 циклов, включающих 5-суточные курсы с 10-суточными перерывами); III группу (контроль) составляли интактные звери, не получавшие антгельминтик и кормовую добавку, IV - интактные звери, в ОР которых добавляли препарат Биоактивный кератин в количестве 0,2 \% от суточной нормы белка (6 циклов - 5-суточные курсы с 10-суточными интервалами).

В период наблюдения молодняк взвешивали индивидуально с точностью до 0,01 кг (электронные весы МП ВД(Ж)А Ф-2, ООО «МИДЛиК», г. Москва, Россия).

Физиологическое состояние зверей оценивали по результатам общего клинического анализа цельной крови (выполнен в лаборатории ГБУ «Московская станция по борьбе с болезнями животных»). Образцы отбирали из латеральной подкожной вены голени (утром после ночного сна до кормления и поения) у 2-месячных щенков до начала опыта и у 7-месяч- 
ных - по его окончании. Определяли содержание гемоглобина, общее число эритроцитов и лейкоцитов, содержание и соотношение основных субпопуляций гранулоцитарных лейкоцитов (лимфоцитов, моноцитов, эозинофилов, нейтрофилов и базофилов), входящих в лейкоцитарную формулу.

По окончании опыта полученные шкурки подвергли первичной обработке и комиссионной оценке качества в соответствии с ГОСТ 279088, а также определяли основные свойства шкурок (площадь, длина и толщина волос различных категорий). Густоту волосяного покрова на огузке определяли прямым подсчетом и по числу корней волос на горизонтальных срезах. Гистосрезы готовили по стандартной методике с окрашиванием гематоксилином и эозином, фиксируя их на заключительном этапе под покровным стеклом канадским бальзамом (11), и просматривали при увеличении ×400 (ZEISS Axio Lab.A1, «Zeiss AG», Германия).

При статистической обработке полученных результатов определяли значения средней арифметической $(M)$ и стандартной ошибки средней $( \pm \mathrm{SEM})$. Статистическую значимость различий средних оценивали по $t$ критерию Стьюдента $(27,28)$.

Результаты. Препарат Ниацид-гранулы плюс изготовлен в виде гранул на основе кормовой приманки и противопаразитарного действующего вещества (антипаразитарная доза 200 мкг ДВ/кг). Согласно перечню требований Государственной фармакопеи XI, проведены исследования органолептических, физико-химических и биологических свойств препарата (29) (табл. 1).

1. Показатели качества антгельминтика Ниацид-гранулы плюс (OOO «НПО «Экобиовет») (29)

\begin{tabular}{l|c}
\hline \multicolumn{1}{c|}{ Показатель } & Характеристика и норма \\
\hline Внешний вид, цвет & \\
Подлинность ДВ (абамектин): & 85 \\
авермектин В $\mathrm{B}_{1 \mathrm{a}}, \%$ (не менее) & 15 \\
авермектин В $\mathrm{B}_{1 \mathrm{~b}}, \%$ (не более) & $200 \pm 20$ мкг $/$ гранула \\
Массовая доля абамектина, $\%$ & $\mathrm{IV} \mathrm{класс} \mathrm{токсичности}$ \\
Токсичность, тест-доза на крысах & Не допускаются \\
Посторонние механические включения & Не менее 21 мес \\
Срок хранения & \\
\hline
\end{tabular}

Как следует из таблицы 1 , действующее начало препарата Ниацидгранулы плюс - комплекс природных негидрированных авермектинов $\mathrm{B}_{1 \mathrm{a}}$ и $\mathrm{B}_{1 \mathrm{~b}}$, которые стабильны только при соблюдении соответствующих установленных режимов хранения (29).

2. Показатели качества препарата Биоактивный кератин (МГАВМиБ-МВА им. К.И. Скрябина) (29)

\begin{tabular}{|c|c|}
\hline Показатель & Характеристика и норма \\
\hline Внешний вид & Однородная жидкая масса \\
\hline Цвет & От светло-серо-бежевого до темно-серо-бежевого \\
\hline Запах & Специфический \\
\hline Водородный показатель & $6,5-7,5$ \\
\hline Подлинность & Положительная реакция на кератин \\
\hline Массовая доля сухого вещества, \% & $3,0-10,0$ \\
\hline Массовая доля кератина в расчете на сухое вещество, \% & $95,0-98,0$ \\
\hline 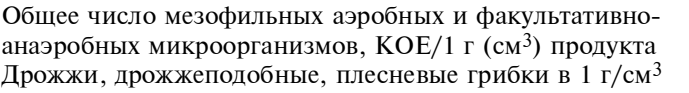 & Не более $1 \times 10^{2}$ \\
\hline продукта & Отсутствие \\
\hline Бактерии семейства Enterobacteriaceac в 1 г/см3 продукта & Отсутствие \\
\hline 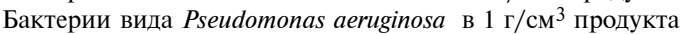 & Отсутствие \\
\hline Бактерии вида Staphylococcus aureus в 1 г/см ${ }^{3}$ продукта & Отсутствие \\
\hline Токсичность, тест-доза на мышах & IV класс токсичности \\
\hline Срок хранения & Не более 2 лет \\
\hline
\end{tabular}


Биоактивный кератин - уникальный по составу и свойствам белок, содержащий серу. Препараты кератина активно используют в медицине и косметологии $(12-14,29)$. Однако этот белок, получаемый из вторичных продуктов шерстеперерабатывающего производства, может быть востребован и в звероводстве в качестве биологической активной добавки к основному рациону пушных зверей. Биоактивный кератин из очеса овечьей шерсти имеет следующие характеристики (табл. 2).

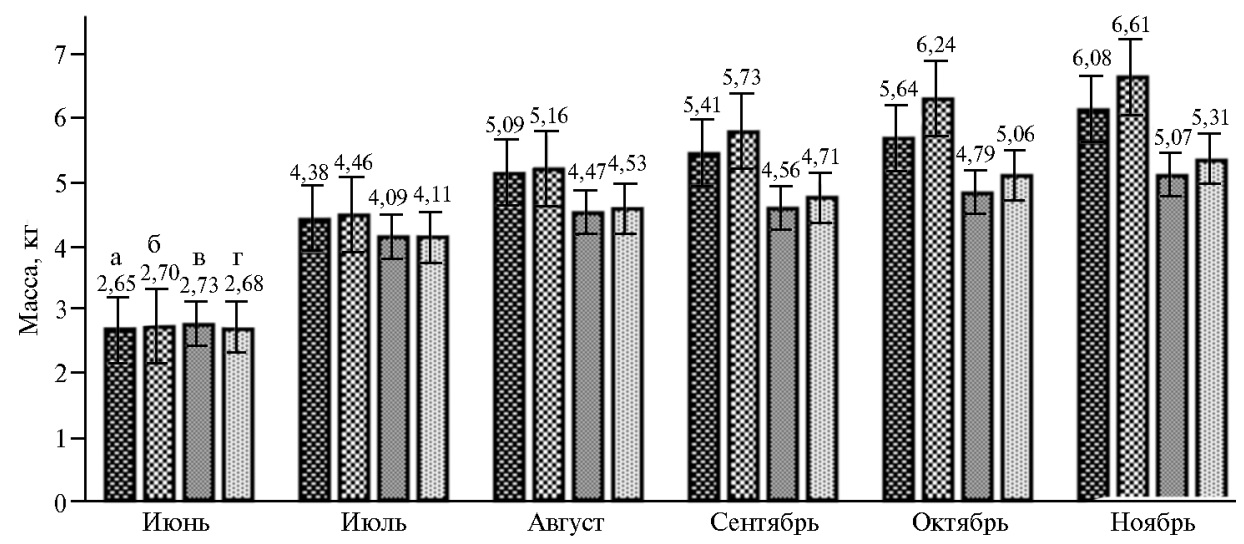

Рис. 1. Динамика массы тела у молодняка серебристо-черной лисицы (Vulpes vulpes L.) при применении антгельминтика Ниацид-гранулы плюс и серосодержащей кормовой добавки Биоактивный кератин: а - Ниацид-гранулы плюс, б - Ниацид-гранулы плюс + Биоактивный кератин, в - интактные звери (контроль), г - Биоактивный кератин (в группе $n=10$, АО «Племенной зверосовхоз «Салтыковский», 2017 год).

В июне перед началом опыта масса 2-месячных щенков во всех группах была примерно одинаковой (рис. 1), статистически значимых различий между группами мы не выявили. Через 1 мес живая масса зверей во всех группах возросла по сравнению с предыдущими показателями в среднем в 1,50-1,65 раза. При этом проявились достоверные различия между массой зверей из I группы, получавших Ниацид-гранулы плюс, и интактных щенков из III группы (контроль) $\left(t_{\text {факт. }}=3,05>t_{\text {табл. }}=2,1\right.$ при $\mathrm{p}=0,05)$. При сравнении массы зверей из II и III групп установили, что при комплексном использовании Ниацид-гранулы плюс и биоактивного кератина масса щенков во II группе была на 9,1 \% выше, чем в контрольной, и примерно на $2 \%$ превышала показатель в случае использования только антгельминтика (соответственно $t_{\text {факт. }}=7,40>t_{\text {табл }}=2,1$ при $\mathrm{p}=0,05$ и $t_{\text {факт. }}=0,81<t_{\text {табл. }}=2,1$ при $\left.\mathrm{p}=0,05\right)$. Сравнение живой массы зверей в II и IV группах также позволило установить между ними статистически достоверные различия $\left(t_{\text {факт. }}=5,46>t_{\text {табл. }}=2,1\right.$ при $\left.\mathrm{p}=0,05\right)$. Таких различий не было между III и IV группами $\left(t_{\text {факт. }}=0,34<t_{\text {табл. }}=2,1\right.$ при $\mathrm{p}=0,05)$. Полученные результаты достоверно свидетельствуют о максимальном положительном эффекте (прирост живой массы щенков) при сочетанном применении препаратов Ниацид-гранулы плюс и Биоактивный кератин. К окончанию периода наблюдения при сравнении средней массы зверей из I группы, получавших противогельминтный препарат, и из контрольной III группы выявили достоверные $\left(t_{\text {факт. }}=9,34>t_{\text {табл. }}=2,1\right.$ при $\mathrm{p}=0,05)$ различия (превышение на $19,9 \%$ ). Между группами II (сочетание двух препаратов) и IV (применение только биоактивного кератина) тоже имелись достоверные $\left(t_{\text {факт. }}=10,11>t_{\text {табл. }}=2,1\right.$ при $\left.\mathrm{p}=0,05\right)$ различия в пользу совместного применения препаратов (прибавка $-24,5$ \%). 
Показатели, характеризующие интенсивность роста молодняка серебристо-черной лисицы, представлены в таблице 3.

3. Прирост живой массы у молодняка серебристо-черной лисицы (Vulpes vulpes L.) при применении антгельминтика Ниацид-гранулы плюс и серосодержащей кормовой добавки Биоактивный кератин $(M \pm \mathrm{SEM}$, в группе $n=10$, АО «Племенной зверосовхоз «Салтыковский», 2017 год)

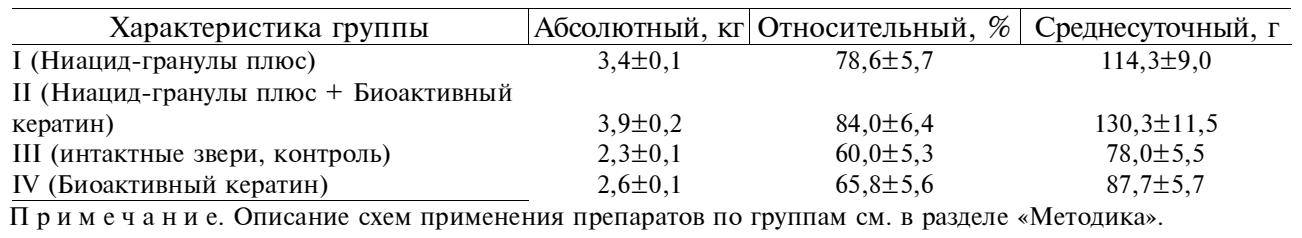

4. Результаты общеклинического анализа крови молодняка серебристо-черной лисицы (Vulpes vulpes L.) при применении антгельминтика Ниацид-гранулы плюс и серосодержащей кормовой добавки Биоактивный кератин ( $M \pm \mathrm{SEM}$, в группе $n=10, \mathrm{AO}$ «Племенной зверосовхоз «Салтыковский», 2017 год)

\begin{tabular}{l|l|l|l|l|l|l}
\hline \multirow{2}{*}{$\begin{array}{l}\text { Характеристика } \\
\text { группы }\end{array}$} & \multicolumn{3}{|c|}{ Начало опыта (1-е сут) } & \multicolumn{3}{c}{ Окончание опыта (210-е сут) } \\
\cline { 2 - 7 } & $\begin{array}{l}\mathrm{HGB}, \\
\text { Г/\% }\end{array}$ & $\begin{array}{l}\text { RBC, } \\
\text { млн/мл }\end{array}$ & $\begin{array}{l}\text { WBC, } \\
\text { тыс/мл }\end{array}$ & $\begin{array}{l}\text { HGB, } \\
\text { г/\% }\end{array}$ & $\begin{array}{l}\text { RBC, } \\
\text { млн/мл }\end{array}$ & $\begin{array}{l}\text { WBC, } \\
\text { тыс/мл }\end{array}$ \\
\hline I (НГП) & $7,9 \pm 0,7$ & $4,2 \pm 0,3$ & $13,8 \pm 0,9$ & $13,2 \pm 1,1$ & $7,3 \pm 0,6$ & $6,4 \pm 0,5$ \\
II (НГП + БК) & $8,4 \pm 0,6$ & $4,0 \pm 0,4$ & $13,6 \pm 1,2$ & $13,9 \pm 1,2$ & $7,7 \pm 0,6$ & $5,3 \pm 0,3$ \\
III (И3, контроль) & $8,2 \pm 0,6$ & $4,4 \pm 0,2$ & $14,4 \pm 1,0$ & $7,0 \pm 0,5$ & $3,9 \pm 0,4$ & $14,8 \pm 1,0$ \\
IV (БК) & $8,0 \pm 0,3$ & $4,3 \pm 0,3$ & $14,1 \pm 1,2$ & $7,3 \pm 0,4$ & $4,0 \pm 0,4$ & $14,4 \pm 1,0$
\end{tabular}

П р и м е ч а н и е. НГП - Ниацид-гранулы плюс, НГП + БК - Ниацид-гранулы плюс + Биоактивный кератин, ИЗ - интактные звери, БК- Биоактивный кератин; HGB (hemoglobin) - гемогеглобин, RBC (red blood cells) - эритроциты, WBC (white blood cells) - лейкоциты. Описание схем применения препаратов по группам см. в разделе «Методика».

Общий клинический анализ крови, позволяющий в целом оценить физиологический статус зверей, показал (табл. 4), что в начале опыта (до использования препаратов), несмотря на некоторые колебания, показатели по группам достоверно не различались. Так, содержание гемоглобина, отвечающего за транспортировку кислорода из легких в ткани и органы, составило от 7,5 до 8,6 \%, эритроцитов - от 4,0 до 4,6 млн/мл, лейкоцитов - от 13,1 до 14,9 тыс/мл. Следует отметить, что в начале опыта щенки еще не были обработаны противогельминтными препаратами и полученные значения, по всей вероятности, указывают на наличие слабой токсокарозной инвазии, причиной которой могло быть заражение как внутриутробно, так и с молоком матери либо в результате заглатывания инвазионных яиц с кормом или водой (30). Известно, что при гельминтозах содержание гемоглобина в крови пушных зверей снижается вследствие кровопотерь из-за постгеморрагической анемии, которую вызывают питающиеся кровью токсокары, повреждающие оболочку кишечника и других внутренних органов $(17,31)$.

После противогельминтной обработки препаратом Ниацид-гранулы плюс (отдельно и в сочетании с серосодержащей кератиновой добавкой) гематологические показатели начинали меняться. В I группе, где применяли только антгельминтик, содержание гемоглобина увеличилось в 1,7 раза, тогда как в III группе (контроль) - к 210-м сут снизилось по сравнению с исходным на $14,6 \%\left(t_{\text {факт. }}=1,30<t_{\text {табл. }}=2,1\right.$ при $\left.\mathrm{p}=0,05\right)$. Установленный факт указывает на усиление инвазии без дегельминтизации молодняка. Во II группе, где совместно с препаратом Ниацид-гранулы плюс использовали биоактивный кератин, уровень гемоглобина повысился в 1,9 раза. В 
IV группе, где звери получали только биоактивный кератин, количество гемоглобина к концу опыта снизилось на $8,75 \%\left(t_{\text {факт. }}=1,40<t_{\text {табл. }}=2,1\right.$ при $\mathrm{p}=0,05)$ от исходного.

Полученные результаты свидетельствуют о том, что препарат Биоактивный кератин, использованный в виде кормовой добавки, несколько тормозил разрушение эритроцитов, а также действовал как дезинтоксикант. Эритроциты выполняют транспортную функцию, обеспечивая снабжение организма кислородом и утилизацию углекислого газа. Исследование красных кровяных телец входит в общий анализ крови при первичной диагностике многих заболеваний, в том числе паразитарных $(17,31)$.

Согласно полученным данным, количество эритроцитов в крови 2месячных щенков серебристо-черной лисицы до начала дегельминтизации варьировало в пределах 4,0-4,6 млн/мл. По-видимому, эти значения характеризуют наличие анемии как следствия патологических процессов в организме щенков, наиболее подверженных воздействию возбудителей токсокароза. Анемия в этом случае может развиться также вследствие недостатка железа, витамина $\mathrm{B}_{12}$ и фолиевой кислоты (4).

После проведения противогельминтных мероприятий число эритроцитов в крови молодняка серебристо-черной лисицы стало повышаться. Так, в I группе (Ниацид-гранулы плюс) оно к концу опыта выросло на $73,8 \%\left(t_{\text {факт. }}=4,62>t_{\text {табл. }}=2,1\right.$ при $\left.\mathrm{p}=0,05\right)$, тогда как в III группе (контроль $)-$ снизилось на $9,3 \%\left(t_{\text {факт. }}=1,12<t_{\text {табл. }}=2,1\right.$ при $\left.\mathrm{p}=0,05\right)$. При сочетании антгельминтика и кормовой добавки тот же показатель вырос на $66,7 \%\left(t_{\text {факт. }}=5,13>t_{\text {табл. }}=2,1\right.$ при $\left.\mathrm{p}=0,05\right)$. В IV группе, где звери получали только кормовую добавку, число эритроцитов в крови к концу опыта снизилась на 7,0\% $\left(t_{\text {факт. }}=0,60<t_{\text {табл. }}=2,1\right.$ при $\left.\mathrm{p}=0,05\right)$ от исходного. Очевидно, пептиды, образующиеся при гидролитическом расщеплении биодобавки в кишечнике пушных зверей, препятствуют разрушению эритроцитов.

Количество лейкоцитов в крови - один из важнейших показателей состояния здоровья особи. Главная функция лейкоцитов - обнаружить чужеродный агент и нейтрализовать его, эти клетки крови - первая линия защиты организма, с которой сталкиваются колонизирующие его патогены, в том числе гельминты $(30,31)$. Содержание лейкоцитов в крови щенков до начала опыта варьировало от 13,4 до 14,4 тыс/мл (см. табл. 4). Эти исходные данные мы рассматриваем как указание на наличие у молодняка патологического процесса в организме, что связано с присутствием гельминтов (так как противогельминтная обработка зверей в тот момент еще не проводилась). В группах I и II (см. табл. 4) число лейкоцитов постепенно снижалось. В группе IV, где звери получали только Биоактивный кератин, количество лейкоцитов было на 2,1\% выше, чем в начале опыта $\left(t_{\text {факт. }}=0,19<t_{\text {табл. }}=2,1\right.$ при $\left.\mathrm{p}=0,05\right)$, но при этом на $2,7 \%$ ниже, чем у зверей из III группы $\left(t_{\text {факт. }}=0,28<t_{\text {табл. }}=2,1\right.$ при $\left.\mathrm{p}=0,05\right)$. При совместном использовании антгельминтика и биодобавки (II группа) содержание лейкоцитов в крови молодняка снизилось в 2,6 раза. Кроме того, обращает на себя внимание тот факт, что биоактивный кератин совместно с антигельминтиком способствуют нормализации состава форменных элементов крови.

Препарат Ниацид-гранулы плюс имел выраженное влияние на площадь шкурок: по сравнению с III группой (контроль) она увеличивалась на $18,1 \%\left(t_{\text {факт. }}=22,60>t_{\text {табл. }}=2,1\right.$ при $\left.\mathrm{p}=0,05\right)$ (табл. 5). 
Сочетание биоактивного кератина с антгельминтиком эффективнее влияло на площадь шкурок: она была на $18,4 \%\left(t_{\text {факт. }}=19,20>t_{\text {табл. }}=2,1\right.$ при $\mathrm{p}=0,05)$ выше, чем в III группе (контроль). Введение в рацион биоактивного кератина без дегельминтизации обеспечило увеличение площади шкурок на $2,7 \%\left(t_{\text {факт. }}=3,87>t_{\text {табл. }}=2,1\right.$ при $\left.\mathrm{p}=0,05\right)$ по сравнению c III группой. Между группами II и IV этот показатель различался на $15,1 \%$ статистически значимо $\left(t_{\text {факт. }}=24,60>t_{\text {табл. }}=2,1\right.$ при $\left.\mathrm{p}=0,05\right)$.

5. Площадь шкурок серебристо-черной лисищы (Vulpes vulpes L.) при применении антгельминтика Ниацид-гранулы плюс и серосодержащей кормовой добавки Биоактивный кератин $(M \pm S E M$, в группе $n=10$, АО «Племенной зверосовхоз «Салтыковский», 2018 год)

\begin{tabular}{|c|c|}
\hline Характеристика группы & Площадь, см ${ }^{2}$ \\
\hline I (Ниацид-гранулы плюс) & $2152,0 \pm 9,5$ \\
\hline II (Ниацид-гранулы плюс + Биоактивный кератин) & $2198,0 \pm 11,0^{*}$ \\
\hline III (интактные звери, контроль) & $1856,0 \pm 9,0$ \\
\hline IV (Биоактивный кератин) & $1909,0 \pm 10,3$ \\
\hline $\begin{array}{l}\text { П р и м е ч а н и е. Описание схем применения препаратов по } \\
\text { дой группе исследовали по } 10 \text { шкурок. } \\
\text { * Различия с контролем статистически значимы при } \mathrm{p}=0,05\end{array}$ & $\begin{array}{l}\text { по группам см. в разделе «Методика». В каж- } \\
05\end{array}$ \\
\hline
\end{tabular}

Эффект от использования препаратов отразился на качестве волосяного покрова. Наибольшая длина всех категорий волос была характерна для боковой области шкурок во всех группах, наименьшую у пуховых и переходных волос отмечали в области огузка, у остевых и направляющих - в хребтовой части (табл. 6).

6. Длина волос (мм) на шкурках серебристо-черной лисицы (Vulpes vulpes L.) при применении антгельминтика Ниацид-гранулы плюс и серосодержащей кормовой добавки Биоактивный кератин ( $M \pm \mathrm{SEM}, n=50$, АО «Племенной зверосовхоз «Салтыковский», 2018 год)

\begin{tabular}{|c|c|c|c|c|}
\hline \multirow{2}{*}{ Характеристика группы } & \multirow{2}{*}{ Категория волос } & \multicolumn{3}{|c|}{ Топографический участок } \\
\hline & & хребет & бок & огузок \\
\hline \multirow{4}{*}{ I (Ниацид-гранулы плюс) } & Пуховые & $44,7 \pm 0,1^{*}$ & $46,3 \pm 0,5^{*}$ & $43,0 \pm 0,8^{*}$ \\
\hline & Переходные & $52,8 \pm 0,3$ & $53,2 \pm 0,3$ & $52,4 \pm 0,6$ \\
\hline & Остевые & $69,8 \pm 0,8$ & $75,7 \pm 0,8$ & $70,5 \pm 0,9$ \\
\hline & Направляющие & $73,0 \pm 0,7$ & $82,0 \pm 0,7$ & $75,7 \pm 0,6$ \\
\hline \multicolumn{2}{|c|}{ II (Ниацид-гранулы плюс + Биоактивный кератин) Пуховые } & $46,9 \pm 0,7^{*}$ & $49,8 \pm 0,4 *$ & $45,9 \pm 0,8^{*}$ \\
\hline \multirow[t]{3}{*}{ (3) } & Переходные & $53,6 \pm 0,4$ & $56,9 \pm 0,5$ & $53,2 \pm 0,3$ \\
\hline & Остевые & $72,2 \pm 0,7$ & $77,2 \pm 0,6$ & $72,9 \pm 0,7$ \\
\hline & Направляющие & $74,1 \pm 0,3$ & $84,5 \pm 0,2$ & $82,3 \pm 0,6$ \\
\hline \multirow[t]{4}{*}{ III (интактные звери, контроль) } & Пуховые & $31,4 \pm 0,2$ & $32,8 \pm 0,4$ & $32,0 \pm 0,4$ \\
\hline & Переходные & $40,2 \pm 0,1$ & $41,7 \pm 0,6$ & $42,1 \pm 0,2$ \\
\hline & Остевые & $37,8 \pm 0,3$ & $26,6 \pm 0,2$ & $27,2 \pm 0,4$ \\
\hline & Направляющие & $62,1 \pm 0,2$ & $54,3 \pm 0,7$ & $57,4 \pm 0,6$ \\
\hline \multirow{4}{*}{ IV (Биоактивный кератин) } & Пуховые & $36,6 \pm 0,1$ & $38,8 \pm 0,6$ & $37,4 \pm 0,4$ \\
\hline & Переходные & $44,0 \pm 0,2$ & $45,6 \pm 0,4$ & $44,1 \pm 0,2$ \\
\hline & Остевые & $48,3 \pm 0,2$ & $36,2 \pm 0,2$ & $31,8 \pm 0,7$ \\
\hline & Направляющие & $65,5 \pm 0,4$ & $58,7 \pm 0,6$ & $60,2 \pm 0,4$ \\
\hline
\end{tabular}

Длина пуховых волос на боковой части шкурок в I и III группах достоверно увеличилась на $4,5 \%\left(t_{\text {факт. }}=2,80>t_{\text {табл. }}=2,1\right.$ при $\left.\mathrm{p}=0,05\right)$ в варианте с использованием только антгельминтика, в II и IV группах при сочетании антгельминтика и биодобавки наблюдали увеличение длины пуховых волос на $4,2 \%\left(t_{\text {факт. }}=3,50>t_{\text {табл. }}=2,1\right.$ при $\left.\mathrm{p}=0,05\right)$. Различия были характерны и для остальных топографических участков, на которых мы проанализировали длину волос (см. табл. 6).

Исследование толщины волос (табл. 7) на различных топографиче- 
ских участках шкурок проводили на тех же образцах, на которых измеряли длину волосяного покрова. Полученные нами данные позволяют сделать вывод, что ни антгельминтик Ниацид-гранулы плюс, ни его сочетание с кормовой добавкой Биоактивный кератин не повлияли на толщину волос шкурок по сравнении с контролем (соответственно $t_{\text {факт. }}=1,8<t_{\text {табл. }}=2,1$ и $t_{\text {факт. }}=1,3<t_{\text {табл. }}=2,1$ при $\left.\mathrm{p}=0,05\right)$. То же отмечали для группы IV.

7. Толщина волос (мкм) на шкурках серебристо-черной лисицы (Vulpes vulpes L.) при применении антгельминтика Ниацид-гранулы плюс и серосодержащей кормовой добавки Биоактивный кератин ( $M \pm \mathrm{SEM}, n=50$, АО «Племенной зверосовхоз «Салтыковский», 2018 год)

\begin{tabular}{|c|c|c|c|c|}
\hline \multirow{2}{*}{ Характеристика группы } & \multirow{2}{*}{ Категория волос } & \multicolumn{3}{|c|}{ Топографический участок } \\
\hline & & хребет & 6оK & огузок \\
\hline \multirow[t]{4}{*}{ I (Ниацид-гранулы плюс) } & Пуховые & $20,4 \pm 0,2$ & $20,3 \pm 0,3$ & $21,8 \pm 0,4$ \\
\hline & Переходные & $47,2 \pm 0,7$ & $45,5 \pm 0,5$ & $50,2 \pm 0,5$ \\
\hline & Остевые & $76,9 \pm 0,7$ & $72,6 \pm 0,7$ & $80,3 \pm 0,6$ \\
\hline & Направляющие & $87,9 \pm 0,7$ & $73,8 \pm 0,2$ & $94,5 \pm 0,6$ \\
\hline \multirow[t]{4}{*}{ II (Ниацид-гранулы плюс + Биоактивный кератин) } & Пуховые & $21,4 \pm 0,2$ & $21,2 \pm 0,4$ & $22,1 \pm 0,3$ \\
\hline & Переходные & $49,9 \pm 0,8$ & $45,3 \pm 0,6$ & $50,0 \pm 0,7$ \\
\hline & Остевые & $80,3 \pm 0,7$ & $75,6 \pm 0,6$ & $85,7 \pm 0,9$ \\
\hline & Направляющие & $96,8 \pm 0,5$ & $95,7 \pm 0,7$ & $97,8 \pm 0,9$ \\
\hline \multirow[t]{4}{*}{ III (интактные звери, контроль) } & Пуховые & $22,4 \pm 0,5$ & $21,7 \pm 0,2$ & $23,6 \pm 0,7$ \\
\hline & Переходные & $36,9 \pm 0,2$ & $35,7 \pm 0,4$ & $37,1 \pm 0,5$ \\
\hline & Остевые & $58,4 \pm 0,6$ & $59,6 \pm 0,6$ & $60,1 \pm 0,4$ \\
\hline & Направляющие & $68,5 \pm 0,4$ & $61,1 \pm 0,7$ & $59,8 \pm 0,6$ \\
\hline \multirow[t]{4}{*}{ IV (Биоактивный кератин) } & Пуховые & $24,3 \pm 0,6$ & $23,8 \pm 0,3$ & $24,8 \pm 0,4$ \\
\hline & Переходные & $37,6 \pm 0,4$ & $37,7 \pm 0,3$ & $39,7 \pm 0,7$ \\
\hline & Остевые & $61,8 \pm 0,9$ & $65,1 \pm 0,9$ & $69,9 \pm 0,3$ \\
\hline & Направляющие & $71,4 \pm 0,6$ & $70,8 \pm 0,3$ & $71,8 \pm 0,6$ \\
\hline
\end{tabular}

Густоту волосяного покрова на шкурке оценивали по числу первичных и вторичных фолликулов, а также прямым подсчетом всех категорий волос на единице площади $\left(1 \mathrm{~cm}^{2}\right)$ образцов, взятых с огузочной части шкурки (табл. 8).

8. Густота волосяного покрова на шкурках серебристо-черной лисицы (Vulpes vulpes L.) при применении антгельминтика Ниацид-гранулы плюс и серосодержащей кормовой добавки Биоактивный кератин ( $M \pm \mathrm{SEM}, n=10$, AO «Племенной зверосовхоз «Салтыковский», 2018 год)

\begin{tabular}{|c|c|c|c|}
\hline \multirow[t]{2}{*}{ Характеристика группы } & \multicolumn{2}{|c|}{$\begin{array}{l}\text { Среднее число волосяных } \\
\text { фолликулов в поле зрения } \\
\text { микроскопа }\end{array}$} & \multirow{2}{*}{$\begin{array}{l}\text { Суммарное число } \\
\text { волос всех катего- } \\
\text { рий на единицу } \\
\text { площади }\left(1 \mathrm{~cm}^{2}\right)\end{array}$} \\
\hline & первичные & вторичные & \\
\hline I (Ниацид-гранулы плюс) & 14,3 & 1,4 & $14322 \pm 468$ \\
\hline II (Ниацид-гранулы плюс + Биоактивный кератин) & 15,7 & 1,6 & $15670 \pm 580^{*}$ \\
\hline III (интактные звери, контроль) & 11,1 & 1,0 & $12576 \pm 462$ \\
\hline IV (Биоактивный кератин) & 12,3 & 1,1 & $13009 \pm 359$ \\
\hline
\end{tabular}

Применение препарата Ниацид-гранулы плюс положительно сказалось на опушении шкурок: суммарное число всех категорий волос в расчете на $1 \mathrm{~cm}^{2}$ было на 13,9\% выше $\left(t_{\text {факт. }}=2,66>t_{\text {табл. }}=2,1\right.$ при р $\left.=0,05\right)$, чем в контроле. Сочетание антгельминтика и биоактивного кератина достоверно $\left(t_{\text {факт. }}=4,17>t_{\text {табл. }}=2,1\right.$ при $\left.\mathrm{p}=0,05\right)$ увеличивало густоту волос на шкурках на 24,6 \% по сравнению с контролем, тогда как только биоактивный кератин - лишь на $3,4 \%\left(t_{\text {факт. }}=0,74<t_{\text {табл. }}=2,1\right.$ при $\left.\mathrm{p}=0,05\right)$. Следовательно, наибольший положительный эффект оказало сочетанное применение исследуемых препаратов. Очевидно, что противогельминтный 
препарат способствовал оздоровлению молодняка серебристо-черной лисицы, благодаря чему биоактивный кератин максимально простимулировал рост более густого волосяного покрова.

Многие авторы отмечают, что именно кератин стимулирует рост волос, повышая их густоту за счет активизации зачаточных фолликулов (11). Для проверки этой гипотезы были приготовлены горизонтальные гистологические срезы с образцов тех же шкурок, взятых с огузочной части (рис. 2).
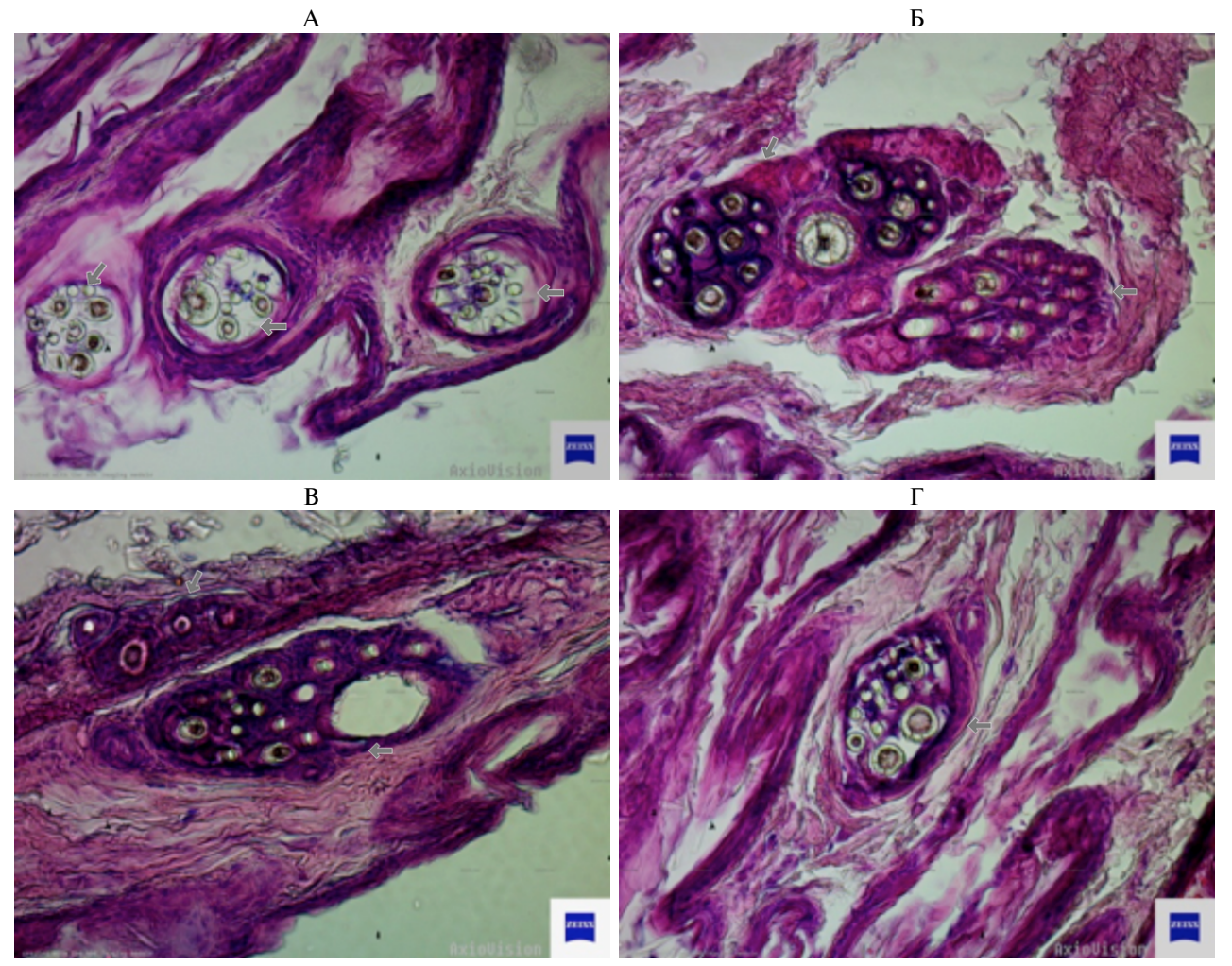

Рис. 2. Горизонтальные гистосрезы кожевой ткани шкурок серебристо-черной лисицы (Vulpes vulpes L.) при применении антгельминтика Ниацид-гранулы плюс (A), антгельминтика Ниацидгранулы плюс в сочетании с серосодержащей кормовой добавкой Биоактивный кератин (Б), у интактных зверей (контроль) (В) и при использовании только серосодержащей кормовой добавки Биоактивный кератин (Г) (АО «Племенной зверосовхоз «Салтыковский», 2018 год). Окрашивание гематоксилином и эозином, увеличение $\times 400$; стрелками отмечены пучки волос.

Полученные данные служат основанием для применения антигельминтного препарата Ниацид-гранулы плюс в сочетании с кормовой добавкой Биоактивный кератин как элемента технологии выращивания убойного молодняка серебристо-черной лисицы для улучшения физиологического состояния зверей и получения более качественных шкурок. Ниацидгранулы плюс рекомендуется использовать 2-кратно с интервалом 10 сут в возрасте 2 мес, а Биоактивный кератин добавлять в основной рацион шестью циклами (5-суточные курсы с 10-суточными перерывами).

Таким образом, дегельминтизация молодняка серебристо-черной лисицы в возрасте 2 мес препаратом нового поколения Ниацид-гранулы плюс и последующее применение препарата Биоактивный кератин в качестве кормовой добавки к основному рациону способствуют ускоренной нормализации физиологического статуса молодняка серебристо-черной 
лисицы, что отражают клинические показатели крови, и достоверно влияют на прирост живой массы. При применении обоих препаратов масса молодняка серебристо-черной лисицы увеличилась на 30,4 \%, площадь полученных шкурок - на 18,4 \%, густота волосяного покрова - на 24,6 \% по сравнению с аналогичными показателями у интактных зверей. Это позволяет рекомендовать Ниацид-гранулы плюс в сочетании с кормовой добавкой Биоактивный кератин для практического применения в зверохозяйствах для улучшения благополучия животных и повышения качества получаемой от них товарной продукции.

\section{ЛИТЕРАТУРА}

1. Canids: foxes, wolves, jackals and dogs. Status survey and conservation action plan /C. SilleroZubiri, M. Hoffmann, D.W. Macdonald (eds.). IUCN, Gland, Switzerland and Cambridge, UK, 2004.

2. Zhang T., Zhong W., Sun W., Wang Z., Sun H., Fan Y., Li G. Effects of dietary fat: carbohydrate ratio on nutrient digestibility, serum parameters, and production performance in male silver foxes (Vulpes vulpes) during the winter fur-growing period. Canadian Journal of Animal Science, 2017, 97(2): 199-206 (doi: 10.1139/CJAS-2015-0167).

3. Juokslahti T., Korhonen T., Oksanen A. Coccidiosis in farmed silver foxes (Vulpes vulpes) and blue foxes (Alopex lagopus) in Finland: a case report. Acta Veterinaria Scandinavica, 2010, 52(supplement 1): S18 (doi: 10.1186/1751-0147-52-S1-S18).

4. Özkan B. Parasitary infestation in a fox. Journal of Istanbul Veterinary Sciences, 2018, 2(1): 1422 (doi: 10.30704/http-www-jivs-net.388610).

5. Lankas G.R., Gordon L.R. Toxicology. In: Ivermectin and avermectin /W.C. Campbell (ed.). Springer-Verlag, NY, 1989: 89-112.

6. Taira K., Saeed I., Kapel C.M. Dose-dependent egg excretion in foxes (Vulpes vulpes) after a single infection with Toxocara canis eggs. Parasitology Reserch, 2002, 88(10): 941-943 (doi: 10.1007/s00436-002-0680-x).

7. Magi M., Guardone L., Macchioni F., Prati M.C., Mignone W. Extraintestinal nematodes of the red fox Vulpes vulpes in north-west Italy. Journal of Helminthology, 2015, 89(4): 506-511 (doi: 10.1017/S0022149X1400025X).

8. Бобова Т.А., Колобов А.В., Заварзин И.В., Джафаров М.Х., Плахтинский В.В., Кулешова Е.С. Новые противопаразитарные препараты на основе авермектина. Тезисы XIX Менделеевского съезда по общей и прикладной химии, Волгоград, 2011, вып. 1: 130.

9. Dyary H.O. Veterinary anthelmintics and anthelmintic drug resistance. Journal of Zankoy Sulaimani. Part-A (Pure and Applied Sciences), 2016, 18(1): 191-206 (doi: 10.17656/jzs. 10463).

10. Prichard R., Ménez C., Lespine A. Moxidectin and the avermectins: consanguinity but not identity. International Journal of Parasitology: Drugs and Drug Resistance, 2012, 2: 134-153 (doi: 10.1016/j.ijpddr.2012.04.001).

11. Василевич Ф.И., Сапожникова А.И., Окутин А.С., Гордиенко И.М., Ручкина 3.С., Бордачёв В.Н. Повышение качества шкурок хоря при использовании продуктов вторичной переработки сырья животного. Сельскохозяйственная биология, 2017, 6(52): 1214-1225 (doi: 10.15389/agrobiology.2017.6.1214rus).

12. Mogosanu G.D., Grumezescu A.M., Chifiriuc M.C. Keratin-based biomaterials for biomedical applications. Current Drug Targets, 2014, 15(5): 518-530 (doi: 10.2174/1389450115666140307154143).

13. Kirsner R.S., Cassidy S., Marsh C., Vivas A., Kelly R.J. Use of a keratin-based wound dressing in the management of wounds in a patient with recessive dystrophic epidermolysis bullosa. Advances in skin and wound care, 2012, 25(9): 400-403 (doi: 10.1097/01.ASW.0000419404.44947.de).

14. Rouse J.G., Van Dyke M.E. A review of keratin-based biomaterials for biomedical applications. Materials, 2010, 3: 999-1014 (doi: 10.3390/ma3020999).

15. Van Heugten E., Van Kempen T.A. Growth performance, carcass characteristics, nutrient digestibility and fecal odorous compounds in growing-finishing pigs fed diets containing hydrolyzed feather meal. Journal of Animal Science, 80(1): 171-178 (doi: 10.2527/2002.801171x).

16. Poole L.B. The basics of thiols and cysteines in redox biology and chemistry. Free Radical Biology and Medicine, 2015, 80: 148-157 (doi: 10.1016/j.freeradbiomed.2014.11.013).

17. Голубков В.А. Эффективность получения водорастворимой формы кератина в присутствии химических восстановителей. В сб.: Экология Южной Сибири и сопредельных территорий. М., 2016: 12.

18. Dröge W., Breitkreutz R. Glutathione and immune function. Proceedings of the Nutrition Society, 2000, 59(4): 595-600 (doi: 10.1017/s0029665100000847). 
19. Ghezzi P. Role of glutathione in immunity and inflammation in the lung. International Journal of General Medicine, 2011, 4: 105-113 (doi: 10.2147/IJGM.S15618).

20. Wang B., Yang W., McKittrick J., Meyers M.A. Keratin: structure, mechanical properties, occurrence in biological organisms, and efforts at bio inspiration. Progress in Materials Science, 2016, 76: 229-318 (doi: 10.1016/j.pmatsci.2015.06.001).

21. Ramms L., Fabris G., Windoffer R., Schwarz N., Springer R., Zhou C., Lazar J., Stiefel S., Hersch N., Schnakenberg U., Magin T.M., Leube R.E., Merkel R., Hoffmann B. Keratins as the main component for the mechanical integrity of keratinocytes. PNAS USA, 2013, 110(46): 18513-18518 (doi: 10.1073/pnas.1313491110).

22. Windoffer R., Beil M., Magin T.M., Leube R.E. Cytoskeleton in motion: the dynamics of keratin intermediate filaments in epithelia. J. Cell Biol., 2011, 194(5): 669-678 (doi: 10.1083/jcb.201008095).

23. Dzhafarov M.Kh., Vasilevich F.I. Ecological, physiological and biochemical adaptation in helminth: trends in evolution of anthelminthic chemical agents (review). Advances in Pharmacology and Pharmacy, 2014, 2: 30-45.

24. Peng Y., Shi Q., Wang Y., Zhang F., Ji Z., Zhang J. Dietary probiotics have different effects on the composition of fecal microbiota in farmed raccoon dog (Nyctereutes procyonoides) and silver fox (Vulpes vulpes fulva). BMC Microbiology, 2019, 19(1): Article number 109 (doi: 10.1186/s12866-019-1491-x).

25. Сапожникова А.И., Каспарьянц С.А., Месропова Н.В., Гордиенко Н.М. Способ получения кератина. А.с. 2092072 (РФ) МКЙ А 23 К 1/10. № 95117245-13. Заявл. 06.10.95. Опубл. 10.10.97. Бюл. № 28.

26. Прозоровский В.Б., Прозоровский М., Демченко В.М. Экспресс-метод определения средней эффективной дозы и ее ошибки. Фармакология и токсикология, 1978, 41(4): 497-502.

27. Боровиков В. STATISTICA. Искусство анализа данных на компьютере. СПб, 2003.

28. Боровков А.А. Математическая статистика. Оценка параметров. Проверка гипотез. М., 1984.

29. Esepenok K.V., Sapozhnikova A.I., Mirzayev M.N. Safety assessment of the "Niacid-granules plus" product and the "Bioactive keratin" sulfur-containing feed additive. Materials of the International Conference «Scientific research of the SCO countries: synergy and integration». Beijing, 2019: 140-148 (doi: 10.34660/INF.2019.16.36671).

30. Написанова Л.А., Жданова О.Б., Окулова И.И., Ашихмин С.П., Березина Ю.А., Часовских О.В. Токсокароз пушных зверей и домашних плотоядных, гематологические показатели. Российский паразитологический журнал, 2016, 2: 210-216.

31. Санжиева С.Е. Морфологические и биохимические показатели крови серебристо-черных лисиц. Аграрный вестник Урала, 2010, 4: 56-58.

${ }_{1}^{1}$ ФББОУ ВО Московская государственная академия ветеринарной медицины и биотехнологии-

МВА им. К.И. Скрябина,

109472 Россия, г. Москва, ул. Академика Скрябина, 23,

e-mail: fibrilla@mail.ru $₫$, opusek@icloud.com, niacid@yandex.ru,

tinaevaea@list.ru;

${ }^{2}$ ФГБНУ НИИ пушного звероводства и кролиководства

им. В.А. Афанасьева,

140143 Россия, Московская обл., Раменский р-н, пос. Родники,

ул. Трудовая, 6 ,

e-mail: gkosovsky@mail.ru, liza.kvartnikova@mail.ru,bnovikov@mail.ru,

tamilachekalova@yandex.ru

Sel'skokhozyaistvennaya biologiya [Agricultural Biology], 2019, V. 54, № 6, pp. 1154-1166

\title{
PHYSIOLOGICAL STATUS AND FUR QUALITY OF YOUNG SILVER FOXES (Vulpes vulpes L.) UNDER USE OF ANTIPARASITIC DRUG NIACID-GRANULES PLUS AND BIOACTIVE KERATIN AS A FEED ADDITIVE
}

\author{
A.I. Sapozhnikova', K.V. Esepenok ${ }^{1}$, G.Yu. Kosovsky², E.A. Tinaeval', M.N. Mirzaev', \\ E.G. Kvartnikova' ${ }^{2}$ B.V. Novikov' ${ }^{2}$ T.M. Chekalova ${ }^{2}$
}

${ }^{1}$ Skryabin Moscow State Academy of Veterinary Medicine and Biotechnology, 23, ul. Akademika K.I. Skryabina, Moscow, 109472 Russia, e-mail fibrilla@mail.ru ( $\square$ corresponding author), opusek@icloud.com, niacid@yandex.ru, tinaevaea@list.ru; 
${ }^{2}$ Afanas'ev Research Institute of Fur-Bearing Animal Breeding and Rabbit Breeding, 6, ul. Trudovaya, pos. Rodniki, Ramenskii Region, Moscow Province, 140143 Russia, e-mail gkosovsky@mail.ru, liza.kvartnikova@mail.ru, bnovikov@mail.ru, tamilachekalova@yandex.ru

ORCID:

Sapozhnikova A.I. orcid.org/0000-0001-5040-6998

Esepenok K.V. orcid.org/0000-0002-3085-6577

Kosovskii G.Yu. orcid.org/0000-0003-3808-3086

Mirzaev M.N. orcid.org/0000-0002-7093-1711

Kvartnikova E.G. orcid.org/0000-0002-5009-0353

Tinaeva E.A. orcid.org/0000-0002-3454-540X

The authors declare no conflict of interests

Received September 29, 2019

Novikov B.V. orcid.org/0000-0002-8850-315X

Chekalova T.M. orcid.org/0000-0002-5476-9750

doi: 10.15389/agrobiology.2019.6.1154eng

\section{Abstract}

Recently, among carnivores, including silver-black foxes, cases of nematode infestation have become more frequent, causing significant economic damage. From helminthic infestations, youngsters suffer the most. Currently, in the veterinary world practice, anthelmintics of the new generation, in particular, avermectin-based products are recognized the most promising. To date, neither in Russia nor abroad, keratin preparations in combination with anthelmintics have been used in fur farming. In the present work, it was experimentally proved for the first time that a newgeneration anthelmintic Niacid-granules plus combined with a sulfur-containing feed additive Bioactive keratin improve fur grading indices (size, amount of fur, completeness of fur, damage to fur, damage to skin etc.) in silver-black foxes (Vulpes vulpes L.). This paper documents physiological effects and fur quality parameters in young silver-black foxes due to the combined use of Bioactive keratin and an avermectin-based anthelmintic. Niacid-granules plus (LLC SPA Ecobiovet, Russia, and Skryabin Moscow State Academy of Veterinary Medicine and Biotechnology, Russia) are brown granules, 300-400 g per pack, with $85 \%$ abamectin $\mathrm{B}_{1 \mathrm{a}}$ and $15 \%$ abamectin $\mathrm{B}_{1 \mathrm{~b}}$ contents and the allowed shelf life for at least 21 months. Bioactive keratin (Skryabin Moscow State Academy of Veterinary Medicine and Biotechnology, Russia) is a monoproduct derived from tow of wool and containing $98 \%$ of native protein, a preparative form of homogeneous liquid mass, color from light gray-beige to dark gray-beige, with a specific smell, mass fraction of dry matter 3$10 \%$, mass fraction of keratin $95-98 \%$, and a shelf life of not more than 2 years. The preparations Niacid-granules plus and Bioactive keratin belong to the IV class of toxicity. It is shown that the combined use of Niacid-granules plus and Bioactive keratin significantly enhances the effect of each drug used separately. In farm tests (AO Saltykovskii Breeding Farm, Moscow Province, 2017-2018), it was found that deworming young silver-black foxes at the age of 2 months with Niacid-granules plus and the subsequent use of dietary Bioactive keratin as a sulfur-containing feed additive significantly affect body weight gain in foxes. Under the combined use of Niacidgranules plus and Bioactive keratin, the live body weight of pups is $9.1 \%$ higher compared to the control ( $t_{\text {fact. }}=7.40 \geq \mathrm{t}_{\text {tab. }}=2.1$ at $\mathrm{p}=0.05$ and $t_{\text {fact. }}=0.81 \leq \mathrm{t}_{\text {tab. }}=2.1$ at $\mathrm{p}=0.05$, respectively). Niacid-granules plus together with Bioactive keratin also improved the complete blood counts during the investigation, thereby contributing to a faster normalization of the physiological status of young silver-black foxes. When using both drugs, the weight of young silver-black foxes increased by $30.4 \%$, the area of the obtained furs by $18.4 \%$, the hair density by $24.6 \%$ compared to these parameters in intact animals. This confirms the effectiveness of the joint use of the studied preparations. The use of Niacid-granules plus are allowed to animals at the age of 2 months, twice at 10-day interval, and the dietary Bioactive keratin should be added to feed in six cycles (5-day cycles with 10-day intervals).

Keywords: Vulpes vulpes L., silver fox, young animals, Niacid-granules plus, avermectin, bioactive keratin, body weight gain, blood indicators, fur quality. 